Research/Technical Note

\title{
The Effect of Variety and Processing Methods on the Functional and Chemical Properties of Rice Flour
}

\author{
Eke-Ejiofor Joy ${ }^{*}$, Nwiganale Ledogo \\ Department of Food Science and Technology, Rivers State University of Science and Technology Nkpolu, Port Harcourt, Nigeria
}

Email address:

joyekee@yahoo.co.uk (Eke-Ejiofor J.)

To cite this article:

Eke-Ejiofor Joy, Nwiganale Ledogo. The Effect of Variety and Processing Methods on the Functional and Chemical Properties of Rice Flour. International Journal of Nutrition and Food Sciences. Vol. 5, No. 1, 2016, pp. 80-84. doi: 10.11648/j.ijnfs.20160501.22

\begin{abstract}
The effect of varieties, local (Abakalike) and foreign (Mama Gold) and two processing methods, semi-dry and wet grinding methods on the characteristics of rice flour were investigated. Functional and chemical properties of the rice flour were analyzed using standard methods. The functional parameters analyzed were dispersibility, relative bulk density, swelling power and water absorption capacity while chemical parameter were moisture content, protein, ash, sugar, starch, amylase and amylopectin. The parameters were influenced by variety and processing methods. Highest dispersibility, relative bulk density and swelling power values were associated with sample A which is the foreign variety, while solubility and water absorption capacity were associated with sample B, which is the local variety, all processed by the semi-dry grinding method. The semi-dry ground rice flour produced highest protein and ash as seen in sample B, while wet milled rice flour were associated with highest moisture and starch contents. The flour produced from the local rice (Abakalike) had highest protein, ash sugar and amylose over the foreign variety with all the parameters showing significant differences.
\end{abstract}

Keywords: Varieties, Processing Methods, Properties, Chemical, Functional, Rice Flour

\section{Introduction}

Flour is the main ingredient for the confectionery industry, making its availability and adequate supply a major economic and political issue at various times throughout history (Palmar, 2000). Wheat is the most common base for flour while maize flour has been used and rice can also be used in the production of flour, though it is relatively uncommon.

Rice is the seed of the grass specie Oryza sativa (Asian Rice) or Oryza glaberrima (African rice). As a cereal grain, it is the most widely consumed staple food for a large part of the world's human population especially in Asia. Rice provides $20 \%$ of the world's dietary energy supply, while wheat supplies $19 \%$ and maize $50 \%$ (FAO, 2004). It is the agricultural commodity with the third highest worldwide production, after sugar cane and maize, (FAOSTAT, 2012).

Rice flour has about $6.5-7 \%$ protein and does not contain gluten and is a good substitute for rye, oat or wheat flour, which causes irritation in the digestive systems of those who are gluten - intolerant. Rice flour is used as a thickening agent and for making rice bread (Hosking, 1997). In most parts of the world, the consumption of wheat based products and other cereals containing gluten present problems for a large number of populations who are allergic to gluten; characterized by an inflammation of the small intestine a disease known as celiac. This calls for an alternative to wheat flour. Furthermore, increase in population as well as increase in consumption rate of wheat based products has posed huge burden on the importation, utilization and availability of wheat. The high cost of wheat flour in non-wheat producing countries such as Nigeria poses a problem to bakery industries and consumers of baked products. Fortunately, in Africa, there are numerous traditional grains with high nutritional quality and health benefit that are underutilized, of which rice is one. These traditional grains can contribute substantially to daily protein need, micronutrients and negligible amounts of fats (Stading, 2006) and increase the potential and utilization of rice. Therefore, the main objectives of the study were to assess the characteristics of the rice flour using semi-dry and wet grinding methods in relation to the functional and chemical properties of rice flour. 


\section{Materials and Methods}

\subsection{Raw Materials}

Rice varieties both local and foreign used for this study were purchased from Mile One market in Diobu, Port Harcourt. Rivers State, Nigeria.

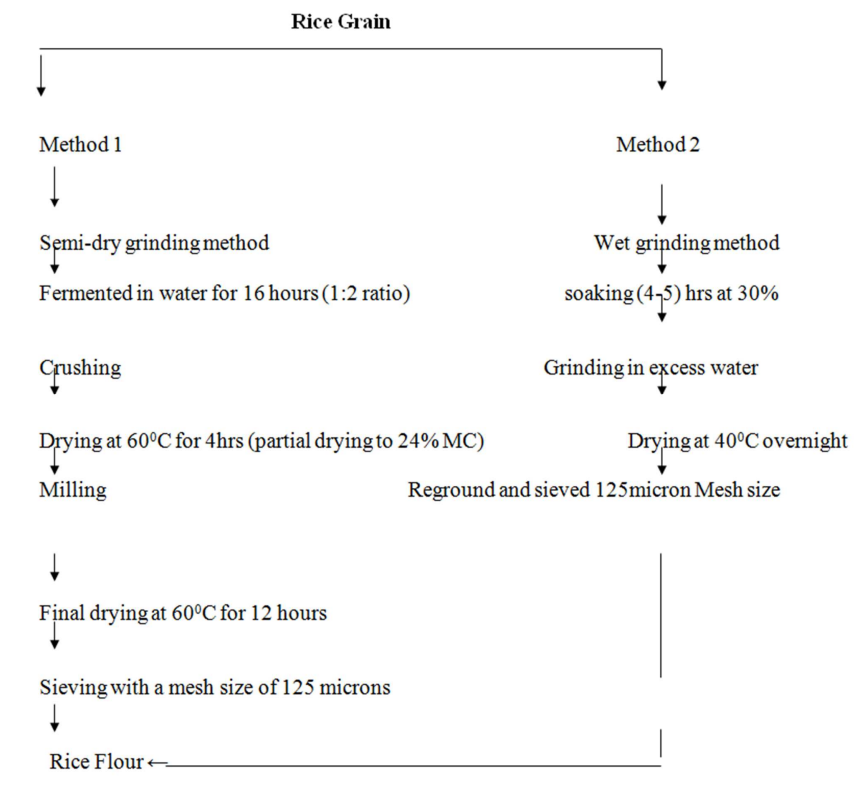

Source: Yeh (2004)

Figure 1. Flow Chart illustrating the production of rice flour.

Preparation of Rice Flour: Rice grains from local and foreign varieties were sorted and cleaned. Two different methods namely semi-dry grinding and wet grinding methods were used to produce rice flour. In the semi-dry grinding method, one and half kilogram $\left(1 /{ }_{2} \mathrm{~kg}\right)$ of the two rice varieties were fermented in $3000 \mathrm{ml}$ of water for 16 hours $(1: 2$ ratio), then crushed and dried at $60^{\circ} \mathrm{C}$ for 4 hours (partial drying) to $24 \%$ moisture content, milled and finally dried at $60^{\circ} \mathrm{C}$ for 12 hours then sieved with a mesh size of 125 microns.
In the wet grinding method, one and half kilogram $\left(1 \frac{1}{2} \mathrm{~kg}\right)$ of the local and foreign rice were soaked in $3000 \mathrm{ml}$ of water for 4-5 hours at $30^{\circ} \mathrm{C}$, milled in excess of water using a wet grinder, dried in a hot air, oven at $40^{\circ} \mathrm{C}$ overnight, reground and sieved with a mesh size of 125 micron to obtain rice flour.

\subsection{Functional Properties of Rice Flour}

Dispersibility was determined by the method of Kulkarni et al., (1991), while the relative bulk density of samples was determined by the method described by Narayana and Narasinya, (1984). The water absorption capacity was determined using the method by Sosulski, (1962), with swelling Power and Solubility determined using the method of Takashi and Sieb, (1988). Moisture, protein and ash contents were determined by the AOAC (1990) method. Amylose content was determined according to the method described by Williams et al., (1970), while amylopectin was calculated by difference $(\%$ Amylopectin $=\%$ starch $-\%$ amylose $)$. Starch and sugar were determined by the method described by Eke 2006 .

\subsection{Statistical Analysis}

The data obtained were subjected to analysis of variance (ANOVA) using (SPSS) version 20.0 software 2007. All analysis was done in duplicate. The measure of central tendencies and dispersions were determined and Duncan Multiple Range Test (DMRT) was used to separate the mean.

\section{Results and Discussion}

Physico-chemical properties of rice flour from semi-dry and wet grinding methods.

The characteristics of rice flour are governed by inherent cultivars variations, environmental variation, the grinding methods and previous treatments (Fan and Marks 1998), which has also affected the finding of the present study.

Table 1: Shows the functional properties of rice flour produced by semi-dry and wet grinding methods.

Table 1. Functional Properties of Rice Flour produced from two methods (Dry and Wet grinding methods.

\begin{tabular}{|c|c|c|c|c|c|c|}
\hline Sample & Dispersibility & Relative & Solubility & Relative Bulk density & Swelling power & Water absorption \\
\hline $\mathrm{A}$ & $67.50^{\mathrm{a}} \pm 1.71$ & $1.53^{\mathrm{a}} \pm 0.07$ & $5.60^{\mathrm{d}} \pm 0.78$ & $1.53^{\mathrm{a}} \pm 0.07$ & $7.75^{\mathrm{a}} \pm 0.35$ & $1.90^{\mathrm{a}} \pm 0.07$ \\
\hline B & $58.00^{\mathrm{b}} \pm 1.41$ & $1.37^{\mathrm{a}} \pm 0.08$ & $10.08^{\mathrm{a}} \pm 0.72$ & $1.37^{\mathrm{a}} \pm 0.08$ & $7.61^{\mathrm{a}} \pm 0.01$ & $2.14^{\mathrm{a}} \pm 0.11$ \\
\hline $\mathrm{C}$ & $60.50^{c} \pm 0.71$ & $1.39^{\mathrm{a}} \pm 0.05$ & $9.07^{\mathrm{b}} \pm 1.16$ & $1.39^{\mathrm{a}} \pm 0.05$ & $7.36^{\mathrm{a}} \pm 0.31$ & $1.94^{\mathrm{a}} \pm 0.05$ \\
\hline
\end{tabular}

Values are mean of duplicate determination \pm Standard deviation

Means having different superscript in the same column are significantly different $(\mathrm{p}<0.05)$.

Key:

Sample A = Foreign Rice Flour Produced Using Semi-Dry Grinding Method (FRFSDGM)

Sample B = Local Rice Flour Produced Using Semi-Dry Grinding Method (LRFSDGM)

Sample C $=$ Foreign Rice Flour Produced Using Wet Grinding Method (FRFWGM)

Sample D = Local Rice Flour Produced Using Wet Grinding Method (LRFWGM)

Dispersibility of rice flours ranged from $58.00 \%-67.50 \%$ with sample B as the lowest and sample A as the highest. The results obtained from the present study showed that there were significant differences $(\mathrm{P}<0.05)$ in the dispersibility of flour samples as a result of the different processing methods and varietal differences. The property of dispersibility determines the tendency of flour to move apart from the water molecules and reveals its hydrophobic action.

The semi-dry grinding method had higher dispersibility than the wet grinding method. Adebowale et al., (2008) reported that flours of higher dispersibility easily reconstitute to give fine consistent dough during mixing. Dispersibility of 
sample A (67.50\%) was significantly higher than sample B $(58.00 \%), \mathrm{C}(60.50 \%)$ and D $(61.00 \%)$. However, the results obtained were lower than the findings of Adebowale et al., (2012) with a value of $73.00 \%-76.50 \%$.

Relative bulk density ranged from $1.34 \mathrm{~g} / \mathrm{ml}$ in sample D as the lowest to $1.53 \mathrm{~g} / \mathrm{ml}$ in sample A as the highest. The present results are higher than the findings of Okoye \& Mazi, (2011) with a maximum value of $0.98 \mathrm{~g} / \mathrm{ml}$. Bulk density is dependent upon the particle size of the samples and can also be described as a measure of heaviness of a flour sample. In agreement with this statement, Akubor and Obieguna (1999) reported that bulk density of a sample could be used in determining its packaging requirements, material handling and application in wet processing in the food industry, as this relates to the load the sample can carry if allowed to rest directly on one another. Processing methods and variety did not have any significant affect on the relative bulk density of the rice flour samples.

Solubility ranged from $5.60 \%-10.08 \%$ with sample A having the lowest value and sample B having the highest. The result of this finding falls within that reported by Eke and Owuno, (2012) who reported a value of $5.36-15.10 \%$ for wheat/three leaf yam composite flour blend. Increase in solubility would result from the shortening of the chain length of the starch molecules with a corresponding weakening of the hydrogen bonds holding the granules together (Sapade and Grys, 1991). Solubility showed significant differences $(\mathrm{P}<$ 0.05 ) in both processing method and variety, with the Wet grinding method having a higher solubility value than the semi-dry grinding method.

Swelling power ranged from $7.36 \%-7.75 \%$ with sample C as the lowest and sample $\mathrm{A}$ as the highest. The result of the present study is lower than the findings of Adebowale, et al (2012) who reported a value of $9.87 \%-10.34 \%$ for sorghum/wheat composite flour. Swelling power is a measure of hydration capacity, because its determination is a weight measure of swollen starch granules and their occluded water. Food eating quality is often connected with retention of water in the swollen starch granules (Rickard et al 1992). Furthermore, swelling power determines the extent to which a flour sample increases in volume when soaked in water in relation to its initial volume. Moorthy and Ramanujam (1980) also reported that the swelling power of flour granules is an indication of the extent of associative forces within the granule, while Loos et al., (1981) also related swelling power to the water absorption index of the starch based flour during heating.

Similarly, water absorption capacity ranged from $1.64 \mathrm{ml} / \mathrm{g}$ $2.14 \mathrm{ml} / \mathrm{g}$ with sample D $(1.64 \mathrm{ml} / \mathrm{g})$ having the lowest value and sample B $(2.14 \mathrm{ml} / \mathrm{g})$ having the highest. This report agreed with the findings of Onabanjo et al (2014) with a value ranging from $1.88 \mathrm{ml} / \mathrm{g}-2.14 \mathrm{ml} / \mathrm{g}$. The disparities observed in the water absorption capacity values could be attributed to the method used as well as the varietal differences. The result obtained shows that the flour has a good ability to bind water. This result suggests that rice flour could be used in confectioneries. Water absorption capacity represents the ability of a product to associate with water under conditions where water is limiting (Singh 2001). Niba et al., (2001) described water absorption capacity as an important processing parameter that has implications for viscosity. Furthermore, water absorption capacity is important in bulking and consistency of products as well as baking applications. High water absorption capacity is attributed to lose structure of starch polymers while low value indicates the compactness of the structure (Adebowale et al., 2005). However swelling power and water absorption capacity were not affected by processing method or variety of rice.

Table 2: shows the chemical properties of the flour samples. Moisture content of the different rice flour samples ranged from $6.58 \%-6.60 \%$ with sample A having the lowest and sample D having the highest value. This finding was slightly higher than that reported by Ocloo et al., (2010) of $6.09 \%$, but lower than that reported by Prasad et al (2012) who reported a moisture content of $(12.11 \%$ to $13.14 \%)$ for Pusa 1121 rice flour. Amornrat and Karmontip (2004) also reported a value of $6.34 \%-8.57 \%$ respectively for wet and dry milled jackfruit seed flour. Moisture provides a measure of the water content of the flour samples and its total solid content. It is also an index of storability of the flour. Reduced moisture content implies better shelf life and stability.

Table 2. Chemical Composite of rice flour produced from two methods (Dry and wet grinding methods).

\begin{tabular}{|c|c|c|c|c|c|c|c|}
\hline Sample & Moisture & Protein & Ash & Starch & Sugar & Amylose & Amylopectin \\
\hline $\mathrm{A}$ & $6.58^{\mathrm{c}} \pm 0.02$ & $7.35^{\mathrm{d}} \pm 0.12$ & $0.92^{\mathrm{b}} \pm 0.04$ & $54.80^{\mathrm{b}} \pm 0.05$ & $1.71^{b} \pm 0.02$ & $32.74^{\mathrm{b}} \pm 0.13$ & $22.06^{\mathrm{c}} \pm 0.13$ \\
\hline B & $6.60^{c} \pm 0.02$ & $8.98^{\mathrm{a}} \pm 0.12$ & $1.14^{\mathrm{a}} \pm 0.02$ & $56.29^{\mathrm{a}} \pm 0.55$ & $1.93^{\mathrm{C}} \pm 0.02$ & $32.85^{\mathrm{a}} \pm 0.13$ & $23.44^{\mathrm{b}} \pm 0.13$ \\
\hline $\mathrm{C}$ & $7.25^{\mathrm{b}} \pm 0.02$ & $7.75^{c} \pm 0.14$ & $0.89^{b} \pm 0.05$ & $56.40^{\mathrm{a}} \pm 0.36$ & $1.78^{\mathrm{a}} \pm 0.02$ & $32.63^{b} \pm 0.13$ & $23.77^{\mathrm{a}} \pm 0.12$ \\
\hline $\mathrm{D}$ & $7.68^{\mathrm{a}} \pm 0.02$ & $8.55^{\mathrm{b}} \pm 0.08$ & $1.05^{\mathrm{a}} \pm 0.02$ & $52.64^{c} \pm 0.27$ & $1.97^{\mathrm{f}} \pm 0.02$ & $32.88^{\mathrm{a}} \pm 0.06$ & $19.76^{\mathrm{d}} \pm 0.06$ \\
\hline
\end{tabular}

Values are mean of duplicate determination \pm Standard deviation

Means having different superscript in the same column are significantly different $(\mathrm{p}<0.05)$.

Key:

Sample A = Foreign Rice Flour Produced Using Semi-Dry Grinding Method (FRFSDGM)

Sample B = Local Rice Flour Produced Using Semi-Dry Grinding Method (LRFSDGM)

Sample C = Foreign Rice Flour Produced Using Wet Grinding Method (FRFWGM)

Sample D = Local Rice Flour Produced Using Wet Grinding Method (LRFWGM)

Protein content of the rice flour ranged from $7.35 \%$ in sample A to $8.98 \%$ in sample B. The present study showed that variety and processing method had significant difference with the local variety having higher protein content. The protein content in the present study falls within the range (6.3-9.5\%) recorded by Derycke, et al (2005). The observed difference may be due to variety and processing methods. To support this finding, Chen (1995), Juliano and Hicks (1996) 
reported that the semi-dry and wet grinding process which involved soaking of rice kernels resulted in leaching out of protein and other soluble substances.

Ash content of the flour samples ranged from $0.89 \%-1.14 \%$ with sample $\mathrm{C}$ having the lowest and sample $\mathrm{B}$ having the highest. The result also showed that ash was less in the wet ground flour than the semi dry ground flour. This finding is in agreement with that of Prasad et al (2012). There was no significant varietal difference $(\mathrm{P} \leq 0.05)$ in ash. Ash is the organic residue remaining after the organic matter has been burnt away (Ocloo et al., 2010).

Sugar content ranged from $1.71 \%-1.97 \%$ with sample A as the lowest and sample D as the highest. The result of the finding is lower than the findings of Adebowale, et al., (2012) who reported a value of $3.97 \%-5.31 \%$ for sorghum /wheat composite flour. Furthermore the local rice variety had more sugar than the foreign rice variety as shown in samples B and D. Chen (1995) reported that some soluble sugars were washed away during soaking of rice kernels which were subjected to semi-dry and wet grinding methods.

Starch content ranged from 52.54\% - 56.40\% with sample $\mathrm{D}$ as the lowest and sample $\mathrm{C}$ as the highest. The starch content ranging from $52.54 \%-56.40 \%$ showed that there was a significant difference $(\mathrm{P}<0.05)$ in samples $\mathrm{A}$ and $\mathrm{D}$.

Amylose content ranged from 32.63\% - 32.88\% with sample C (32.63\%) as the lowest and sample D (32.88\%) as the highest. The result of this finding was higher than the findings of Prasad et al (2012) who reported a value of $16.21 \%$ and $17.81 \%$ for wet and semi dry ground flour respectively. Eke and Owuno, (2012) also reported a lower value of $29.27 \%$ - $32.21 \%$ for wheat/three - leaf yam composite flour blend. Fan and Marks (1998) also reported that rice flour mainly differ in the amylase content which determine the gelatinization temperature and in general the pasting behavior and viscoelastic properties. The amylose content of raw materials is an important factor with regard to the end use properties of various products such as noddles (Sievert and Lausanne 1993). Juliano and Perdon (1975), reported that rice varieties are classified according to their amylose content which can either be non-waxy (8-37\%) or waxy glutinous $(0.8-1.3 \%)$. This has also shown that the rice varieties under review are non- waxy. Raja and Ramakrishma (1990) reported that heat treatment caused a reduction in amylose content of starch based products. However, the processing methods did not affect the amylose contents of the two rice varieties.

The amylopectin content ranging from $19.76 \%-23.76 \%$ was lower than the findings of Eke and Owuno, (2012) who reported a value of $66.27-76.79 \%$ for wheat /three-leaf ram composite flour blend. The observed difference may be as a result of their different origin.

The results from the physical damage of the native amylopectin lead to the degradation of the flour into low molecular weight fragments which may disrupt the glycosidic linkages and the disulphide bonds of the native grain (Prasad et al., 2012). The result of the present study has shown that amylopectin is a function of the starch and amylose content of flour meaning that one is a function of the other and both properties are important in food preparation and development. Amylopectin contributes to high viscosity and waxiness in starch (Eke-Ejiofor and Kin-Kabari, 2010). There were significant differences $(\mathrm{P} \leq 0.05)$ in the processing methods for all the chemical parameters determined.

\section{Conclusion}

The present study showed that different processing methods and variety resulted in variation in the functional and chemical characteristics of rice flour for different uses. The semi-dry grinding method was more suitable for the production of rice flour in terms of its functional properties as it had better solubility and water absorption capacity, while local rice was more preferred to foreign variety as it had better protein, ash sugar and amylase contents.

\section{References}

[1] Adebowale, A. A., Sanni, L. O. and Awonarin, S. O: (2005). Effect of texture modifiers on the physicochemical and sensory properties of dried fufu. Food Sci and Technol. Int11: 373-385.

[2] Adebowale, A. A. Sanni, L. O and Onitilo. M. O (2008). Chemical composition and pasting properties of Tapioca grits from different cassava varieties and roasting methods. African Journal of Food Science, Vol. 2 p. 77-82.

[3] Adebowale, A. A. Adegoke, M. T. Sanni, S. A, Adegunwa, M. O. and Fetuga, G. O. (2012). Functional properties and biscuit making potentials of sorghum - Wheat composite flour. American Journal of Food Technology 7(6): 372-379, ISSN 1557- 4571/001.

[4] Akubor, P. L. Obiegbuna J. E. (1999). "Certain chemical and functional properties of ungerminated and germinated millet flour", J. Food Sci. Technol.; 36: 241-243.

[5] Amornrat, M and Karmontip, S. (2004): "Physicochemical properties of flour and starch from jackfruit seed (Artocarpusheterophyllus lam) compared with modified starches". International Journal of Food Science and Technology, 39, 271-276.

[6] Association of Official Analytical Chemists (AOAC), 1990. Official Method of Analysis, 17th Edition. Washington DC, USA Chen, J. J. (1995). Effect of milling methods on the physicochemical properties of waxy rice flour. Cereal Chemistry 76(5): 796-799.

[7] Derycke, V; Veraverbeke, W. S; Vandeputte, G. E; De Mar, W; Hoseney, R. C. and Delcour, J. A (2005): "Impact of Proteins on Pasting and cooling properties of Nonparboiled and Parboiled rice". Cereal Chemistry Vol. 82, No. 4.

[8] Eke-Ejiofor J. and Owuno, F. (2012). "Functional and pasting properties of wheat/three leaf (Dioscoreadumetorum) composite flour blend". Global Research Journal of Agricultural and Biological Science. 3(4) pp. 330-335.

[9] Eke-Ejiofor J. and Kin-Kabari D. B. (2010): Chemical Properties of Sweet and Irish Potato Chips. Nigerian Food Journal, Vol. 28, (2) 2010 pp. 47-52. 
[10] Fan, J and Marks, B. P. (1998). Retrogradation kinetics of rice flour as influenced by cultivar. Cereal Chem. 75: 153-155.

[11] FAO (2004). A cassava Industrial Revolution in Nigeria.www.faoorg.accessed. Hosking, Richard (1997). A dictionary of Japanese food, Tuttle publishing, p. 191. ISB 9780804820424.

[12] Juliano, B. O and Perdon, A. A. (1975). Gel and molecular properties of non-waxy rice. Starch 27(4): 115-120.

[13] Juliano, B. O and Hicks, P. A. (1996). Rice functional properties and rice food products. Food Reviews International 12: $71-103$.

[14] Kulkarni, K. D; Kulkarni, D. N. \& Ingle, U. M. (1991): "Sorghum Malt-based Weaning formulations, Preparation, functional properties and nutritine Values". Food and Nutrition Bulletin 13 (4): 322-327.

[15] Loos, P. J. Hood L. F and Graham A. J (1981). Isolation and characterization of starch from breadfruit. Cerea chem., 58: 282-2861.

[16] Moorthy, S. N and Ramanujam, T. (1986). Variation in properties of starch in cassava varieties in Relation to age of the crop. Starch starke, 38: 58-61.

[17] Narayana, K. Narasinga Rao M. S. Functional properties of raw and heat processed winged bean flour, J. food sci. 1982: 42: 534-538.

[18] Niba, L. L., Bokanga, M. M., Jackson, F. L., Schllmme, D. S. and Li, B. W. (2001): Physiochemical properties and starch granular characteristics of flour from various Manihotesculents (cassava) genotypes. Journal of Food Science, 67(5).

[19] Ocloo, F. C. K, Bansa, D. Boatin, R. Adom, T. Agbemavor, W. S. (2010): Physicochemical, functional and pasting characteristics of flour produced from jackfruits (Artocarpusheterophyllus) seeds. Agric and Biology Journal of North America, 1(5): 903-908.

[20] Okoye, J. I. \& Mazi, E. A. (2011). "Proximate composition and functional properties of Kidney bean - Wheat flour blends". ABSU Journal of Environment, Science and Technology, Vol. 1: 113-118.

[21] Onabanjo, O. O. \& Ighee Dickson A. (2014). "Nutritional, functional and sensory properties of Biscuit produced from Wheat sweet potato composites". Journal of Food Technology Research 1 (3): 111-121.
[22] Palmer, John. J. (2001) How to Brew: Ingredients, methods, recipes and equipment specialty of Can Thocity. Defenestrative Pub Co. p. 233. ISBN 0-9710579-0- 7.

[23] Prasad, K. Singh, Y and Anil. A (2012). Effects of grinding methods on the characteristics of Pusa 1121 rice flour. J. Trop. Agric and Food Science. Vol. 40(2) p 193-201.

[24] Raja, K. C. M., and Ramakrishma S. U. (1990): Compositional and pasting characteristics of plain-dried and par-boiled cassava (Manihotesculentacrantz). Food Chemistry 38: $79-88$

[25] Rickard, J. E, Blanshard, J. M. V., Asaoka, M. (1992): Effects of cultivar and growth season on the gelatinization properties of cassava (Manihotesculenta) starch. J. Science Food and Agriculture, (59) 53-58.

[26] Sapade, P. A. and Le Grys, G. A. (1991): “An Investigation into the effect of extrusion cooking on the properties of maize starch extrudate". Nigeria Food Journal 9, 49-66.

[27] Sievert, D and Lausanne, J. H. (1993). Determination of amylose by differential scanning calorometry. Starch/sharke 45 (4): 136-139.

[28] Singh U (2001). "Functional properties of grain legume flours", J. Food sci. Technol 38: 191-199.

[29] Sosulski, F. N. (1962). "The centrifugal method for determining flour absorptive. Chemistry" 39: 344-346.

[30] Stading, M. (2006). Introduction to traditional grains. www.sik.se/traditional grains/review. (Accessed $25^{\text {th }}$ February, 2011).

[31] Takashi, S. \& Sieb, P. A. (1988): Paste and gel properties of prime corn and wheat starches with and without native lipids". Cereal Chemistry 65: 474-475.

[32] Williams, P. C. Kuzina, F. D. \&Hynka, I. A. (1970): A rapid calorimetric procedure for estimating the amylase content of starches and starch". Cereal Chemistry 47 (4): 411-413.

[33] Yeh, A. I (2004). Preparation and application of rice In: Champagne, E. T. ed. Rice: Chemistry and Tecnology, $3^{\text {rd }}$ edn. St Paul, MN: American Association of Cereal Chemists, pp, 495-540. 